\title{
Ideational meanings of science and interpersonal position of readers in science textbooks for basic level in Indonesia
}

\author{
Budi Hermawan $^{1^{*}}$ and F.X. Rahyono ${ }^{2}$ \\ ${ }^{1}$ Department of English Education, Faculty of Language and Literature Education, Universitas Pendidikan Indonesia, \\ Jl. Dr. Setiabudhi No. 229 Bandung, West Java, Indonesia \\ ${ }^{2}$ Department of Linguistics, Faculty of Humanities, Universitas Indonesia, Fakultas Ilmu Pengetahuan Budaya, Gd. 3 , \\ Kampus Universitas Indonesia, Depok, Jawa Barat, Indonesia
}

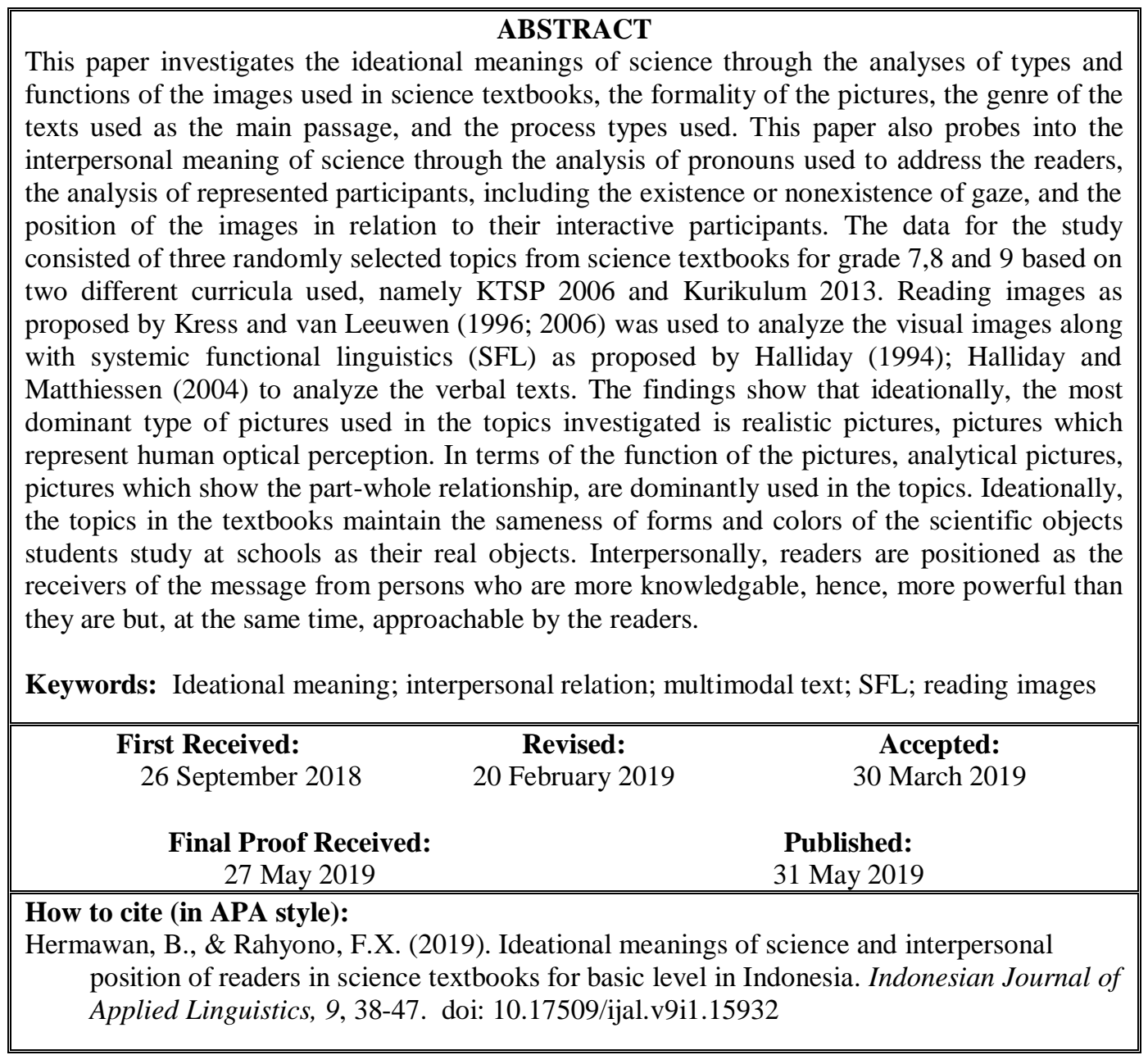

\section{INTRODUCTION}

It is a fact that science textbooks used in Indonesia for grade 7, 8, and 9 make use of a great number of images appearing together with the verbal texts. The visuals in their various forms such as photographs, diagrams, and tables, are not only used to serve as decoration but they are actually co-deployed with the verbal-based semiotic resources on the belief that they will facilitate readers' understanding of the scientific messages communicated in the textbooks. Lynch (1990, in Guo 2004, p. 196), for example, believes that pictures in science texts do more than just supply illustration. They can clarify the verbal text by giving examples, elaborating, or even communicating what the verbal cannot. Best, Rowe, Ozuru, and McNamara (2005) believe that comprehending science involves making good inferences, which are influenced not only by background knowledge and reading strategies but also

\footnotetext{
* Corresponding Author

Email: linguistikmakna@gmail.com
} 
by how the text is presented. This means the codeployment of verbal and visual text will have an influence on the readers' understanding of science. Other researchers who share the belief that illustration can facilitate learning include Mayer (1989), Mayer and Gallini (1990), Mayer and Simms (1994), Harp and Mayer (1997), Carnel and Levin (2002), Kirsh (2002), Mayer, et al. (2005).

The use of images in science textbooks is based on the belief that images help students comprehend the learning materials communicated by the textbooks. Mayer (2001, in Schnotz and Kurschner, 2007) found that students get a better understanding of technical tools or natural phenomena when learning from both text and pictures than they do from written text only. For example in Biology, cell structure that cannot be dissected in real life can be presented clearly using maximum perspective through pictures (Kirsh, 2002), and this way helps students understand the cell structure better than when they only read the description on the cell.

Science textbooks used for basic education, grade 7 through 9 in Indonesia integrate Biology and Physics into one. Physics lessons in this level use many modellings of natural phenomena, for example, water cycle. Biology, on the other hand, needs to present humans', plants' and animals' anatomy using maximum perspective in order for the parts to be able to be observed. This has encouraged a high demand for the use of images in the textbooks.

The increasing use of images with high intensity and quality in science textbooks show two important things. First, though, images will not totally replace the verbal, their ability to communicate scientific messages that will better facilitate students to learn the material is more strongly believed. Second, as images have different characteristics from the verbal text, the ability to read images becomes the competence that should be possessed by the science textbook users in addition to the obvious competence; their ability to read the verbal text.

Part of the competence to read visual text is having adequate knowledge of the types and functions served by images and how they communicate scientific messages. In addition, as science textbooks are multimodal in nature, it is important to discover and learn how these different modes, in particular, verbal and visual text that are frequently co-deployed, interact with each other to communicate the textbooks' scientific messages to their readers.

The knowledge of types and functions of images will facilitate the textbooks'readers'understanding of how images construct and communicate the world and, in the particular case of pictures that appear together with verbal text, how the images relate and translate the world told by the verbal into the world shown by the images. For textbook's illustrators, this knowledge will be useful for the selection of images to be used and how they should effectively present them on the textbooks.
In the context of Indonesia, research on science education has been focused on how to improve teachers competence in developing assessment instruments (e.g. Prasetya, 2012); teaching material development (e.g. Arlitasari, Pujayanto, and Budiharti, 2013); science learning model and techniques (e.g. Wiyono, Setiawan, and Suhandi, 2009; Widiatmoko and Pamelasari, 2012); and on the influence of motivation on students learning results (e.g. Hamdu and Agustina, 2011). It was, at the time the investigation began, very challenging to find research and investigation in Indonesia that focuses on how the modes, in particular, visual mode, used in science textbooks communicate their scientific meanings, on how ideationally science is represented through both verbal and visual texts, and on how interpersonal relation despite being imaginary, between the scientific messages communicated in the textbooks and their readers is constructed. This is an important reason encouraging the investigation reported in the article.

Previous relevant research which probes into the pedagogic function of images in science textbook was conducted by Dimopoulos, Koulaidis, and Sklaveniti (2003). They compared the pictures used to communicate scientific information in Greek science textbooks with pictures used in scientific press articles to investigate the pedagogic functions of pictures and the interpersonal relation, the visual framing, to use their term, between the pictures and the readers. They applied reading images perspectives as proposed by Kress and van Leeuwen (2006), the idea of framing, control on communication established by texts, from Bernstein (1996), and Halliday' modality theory (1996) in their investigation. Darian (2001) provides a comprehensive role or function images perform in science textbooks. However, he uses a different approach in determining and discussing the images' role from the ones used in this article.

While it is relatively easy to accept the idea that the visuals such as pictures construe and communicate messages or experiences as linguistic signs in the form of sentences do, it is quite challenging to embrace the idea that pictures, like the verbal sentences we exchange in direct communication, can establish a social relation with their viewers. Not many were convinced, at least at the beginning, that in the action of viewing or 'relating with picture' our social position is being created the same way we are connecting with other individuals using verbal signs.

The idea that interpersonal relation is constructed between pictures and their viewers derives from Kress and van Leeuwen's idea who extended Halliday's metafunction theory $(1985,1994)$ into pictures. Kress and van Leeuwen (KvL, 1990; 2006.) strongly believe that pictures can perform all three metafunctions; ideational, interpersonal, and textual, like verbal text does. Like verbal text, pictures communicate the ideas, the thoughts, the experience of their designers. Pictures, they argue, are drawn and designed to say something their designers want to say the same way sentences are 
arranged and used by us to say how we feel, how we respond to something. In short, they are used to tell the world the experiences we experience. This is ideational metafunction. Like verbal language, $\mathrm{KvL}$ proposes, pictures act on their viewers the same way verbal sentences an individual produces act on his/her interlocutors. The only difference is, in KvL's opinion, communication involving a viewer and a visual text, the pictures they view is indirect. Hence, it is imaginary in the sense that as the designers of the text are not present at the time of the viewing, the viewers may have to imagine them. It is, nonetheless, a communication between a viewer, the pictures, and the designers of the pictures. This is interpersonal metafunction of pictures. As with verbal sentences that have to be arranged in certain arrangement to form a coherent text to be understood, pictures have to follow and be laid in certain compositional layout to create coherence among their elements to be understood. This is the textual metafunction of pictures.

In addition to KvL's works (1992, 1996, 1998, 2006), the extension of metafunction theory of Systemic Functional Linguistics has also been performed on displayed arts (O'Toole, 1994), on action (Martinec, 1998) on mathematical symbols (O'Halloran, 2005) on films (Baldry and Thibault, 2006)

In explaining the structure realised by pictures, $\mathrm{KvL}$ (2006) propose that pictures possess two representational structures; narrative and conceptual. The following diagram sums up the structures.

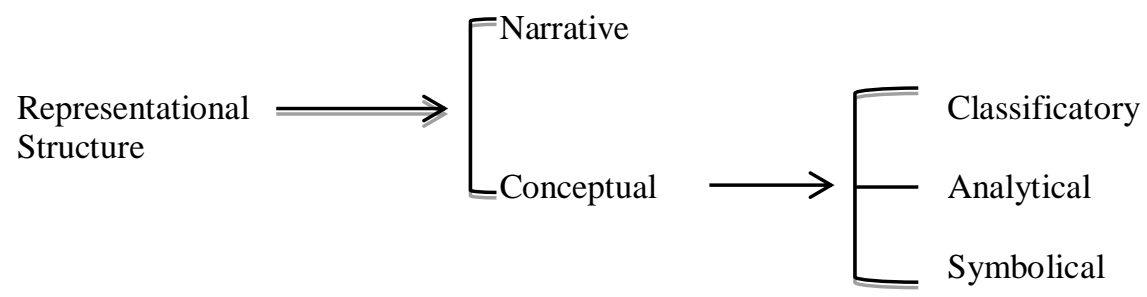

Figure 1. Main types of visual representational structure (KvL, 2006. p. 59)

Narrative structure functions to show ongoing activities and events, the process of change, and transitory spatial arrangements. In narrative structure represented participants are connected by a vector in the form of an arrow or that which looks like it, or by an imaginary line or by that which can be made based on what appears on the picture, which represents actions performed by a participant too, or for another participant in the picture.

Conceptual structure is categorised into classificational, analytical, dan symbolical. In pictures with a classificational structure, one represented participant is related to another represented participant in a "type of.." relation in a taxonomical relation. Example of these pictures is a tree diagram depicting a hierarchical structure of an organization.

A picture with an analytical structure relates represented participants to other represented participants in the picture in a "part-whole relation". Examples of these pictures are maps and car machine schema. Pictures with the symbolic structure are pictures which contain "what a participant means or is (p.105)". The pictures possess meaning beyond themselves. An example of this picture is an expressionist landscape (KvL, 2006).

This paper has employed KvL's perspectives in its analysis of the functions of pictures used in the topics investigated along with Dimopoulos et al.'s (2003) elaboration on types of pictures, which categorises pictures into realistic images; pictures which represent human optical perception, conventional images; pictures which represent reality in a codified way, and hybrid images; pictures which shows elements of realistic and conventional pictures. KvL's reading images have also been used to analyze how the two modes construct an interpersonal relation with their readers in the topics investigated. Halliday's transitivity system is used to unearth and discuss how science is ideationally represented in verbal texts and pictures. Halliday's interpersonal metafunction theory has also been used to look into how the readers are socially related to the scientific messages contained in the topics/to the textbooks writers, and to the pictures. However, as the textbooks are written in Bahasa Indonesia which has different concept and realization of finiteness which serve as part of the mood system, a system to unearth the interpersonal meaning, the interpersonal meaning in this investigation will center on other areas equally important to realise interpersonal meanings, which are investigating and discussing the text genre used in the reading passages, the pronouns used, and the modals used to realise modality in the reading passages. For these purposes, Martin and Rose (2007) ideas on genres in science have been consulted along with Alwi's (1992) explanation on the modality in Bahasa Indonesia.

\section{METHOD}

The selection of the topics/chapters to be investigated was based on the field information gathered through the questionnaire distributed to 31 science teachers who are members of Science Teachers Discussion Group, which is locally named Musyawarah Guru Mata Pelajaran IPA (MGMP IPA/Sains), of Bandung Regency, West Java. The respondents were selected because the writer has good personal access to them.

The topics that serve as the data for the investigation are the topics considered by the teachers 
the most difficult topics to teach to and be mastered by their students. The teachers were initially asked to mention two topics for each grade, so in total, there were six topics, two for each level for each curriculum. For the purpose of the investigation reported here, three topics are presented, one topic for each level each curriculum.

The selected topics analysed were Pengklasifikasian Mahkluk Hidup (Classification of Living Things) for grade 7, Struktur Tumbuhan (Plants Structure) for grade 8, and Listrik Dinamis (Dynamic Electricity) for grade 9. All these topics are from textbooks based on two different curriculums, which are KTSP 2006 and Kurikulum 2013. The textbooks analysed were downloaded from puskurbuk.com, a government-managed site providing electronic textbooks for free downloads and from Bukupaket.com. an accessible site that provides BSE, buku sumber elektronik, electronic sourcebooks. There are plenty of textbooks from different writers to choose from. The textbooks chosen for the investigation are mostly based on their easy accessibility and the consideration that because all the textbooks version from those different writers have gone through formal selection and rigorous examination of the textbooks writing committee employed by National Books Center, any textbook version will have the same format, exactly the same teaching materials, and the same values mandated by the curriculums.

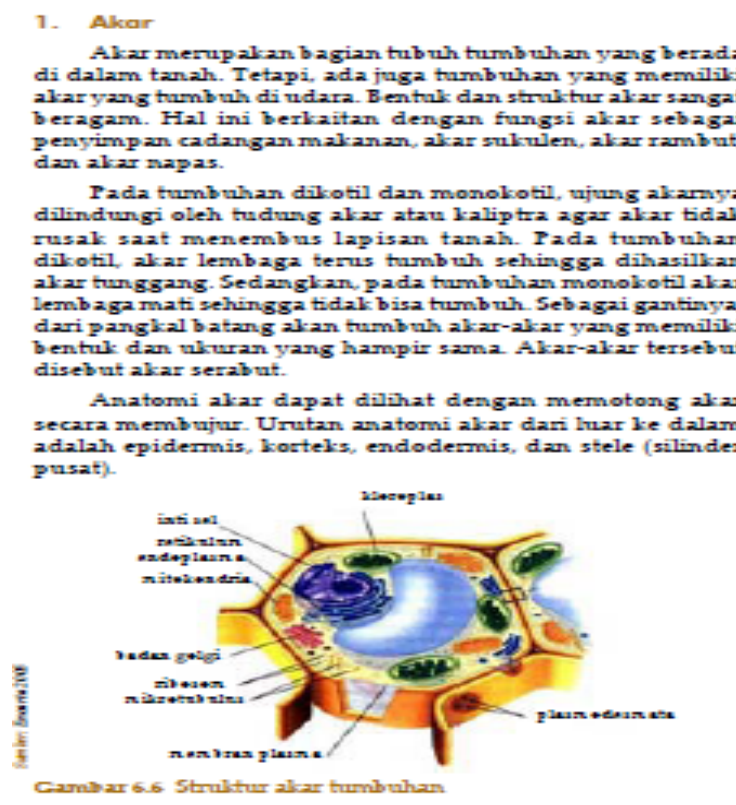

Figure 2. Example of the reading passage

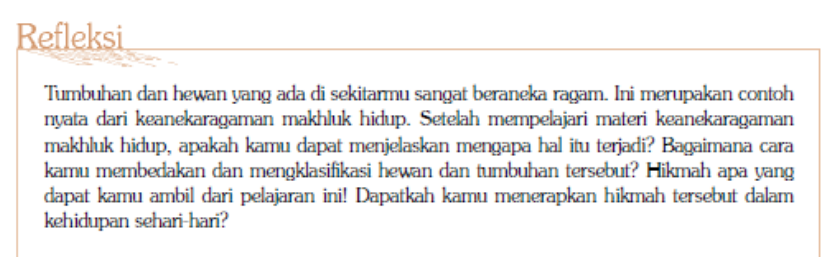

Figure 3. Example of reflection text
The analysis was focused only on main passages used to convey the lesson, excluding those such as Introductory Texts, Summaries, Reflection and Application Texts, and Exercises (see Figures 2-7)

In the area of ideational meanings of science, the analysis was conducted on both the verbal text and the pictures. In the analysis of the verbal text, the reading passages of the topics investigated were broken down into their clauses constituents. Transitivity system was then applied to identify the participants, the types of process used and the circumstance. This was intended to reveal the ideational meanings of the verbal text. The same procedure was applied to the pictures co-deployed in the same page as the verbal text appears. To borrow Royce's term (2002), visual transitivity analysis was conducted on the pictures to identify the participants, the types of process, and the circumstance. This was to discover the ideational meanings of the pictures. The analysis of the pictures also covers the types and functions of the pictures and the formality/modality of the pictures.

In the area of interpersonal meanings of science, the analysis of the verbal text was centred on identifying the genre of the texts used as the main passage, the pronouns used to address the readers, and the modals used for modality in the text. Analysis of the pictures was focused on identifying the represented participants, the absence or presence of gaze, the size of represented participants in the pictures, and their relative position to the readers, or the interactive participants.

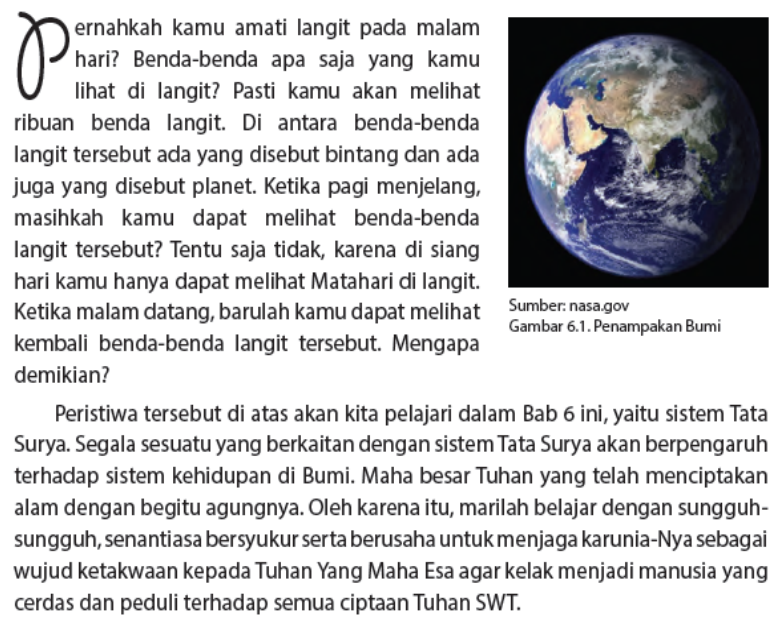

Figure 4. Example of introductory text

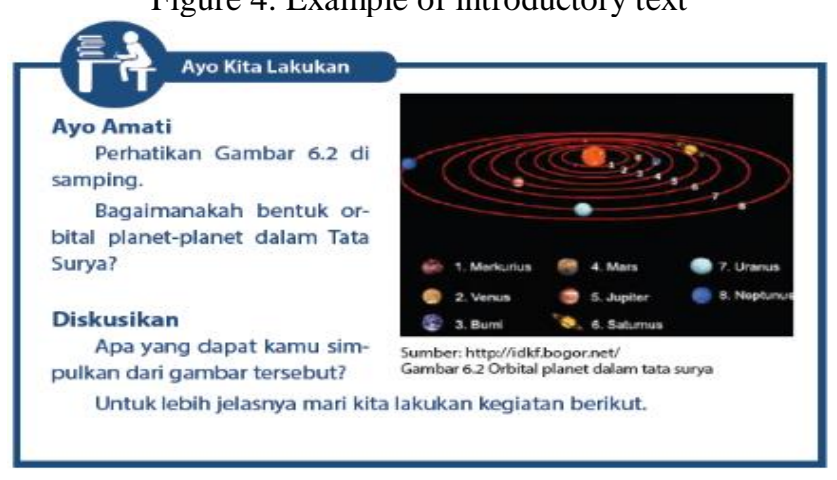

Figure 5. Example of application text 


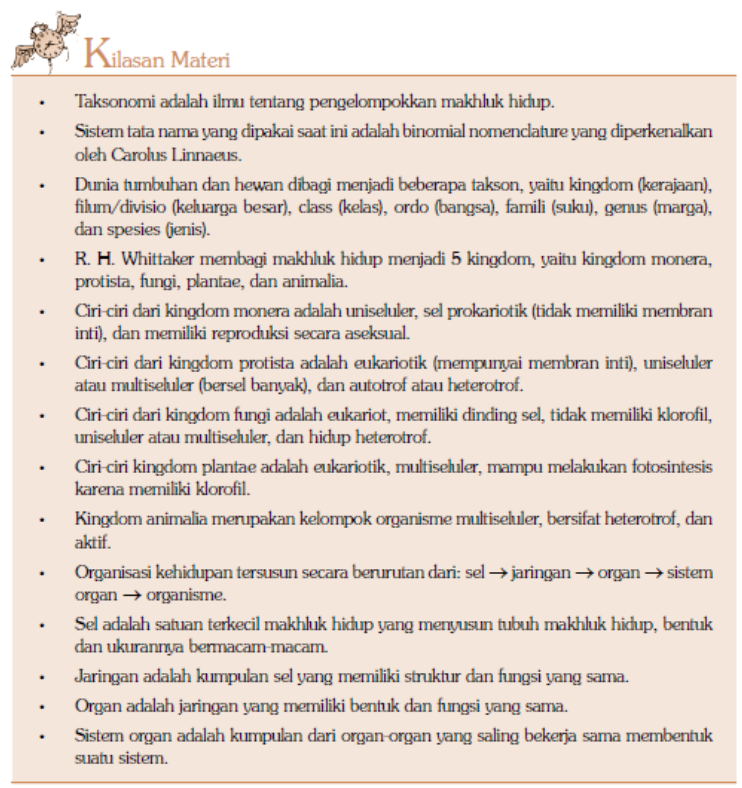

Figure 6. Example of summary

\section{RESULTS AND DISCUSSION \\ Ideational meaning of pictures Types and functions of pictures}

The analysis found that in terms of types of pictures used in the topics investigated, realistics pictures, pictures which represent human optical perception are used dominantly in the textbooks with both curriculums. The topics in the science textbooks with KTSP 2006 used 66 realistics pictures out of 77 total pictures, while science textbooks with Kurikulum 2013 used 74 realistics pictures out of 79 total pictures. In term of the functions of pictures, analytical pictures, pictures which show the part-whole relationship, are dominantly used in the textbooks. The following table sums up the finding.

Table 1. Types of picture in the topics

\begin{tabular}{lccr}
\hline \multirow{2}{*}{$\begin{array}{c}\text { Types of } \\
\text { Pictures }\end{array}$} & \multicolumn{3}{c}{ Curriculum } \\
\cline { 2 - 4 } & KTSP & Kurikulum & \multirow{2}{*}{ Total } \\
\hline Realistic & 66 & $\mathbf{2 0 1 3}$ & 140 \\
Conventional & 4 & 2 & 15 \\
Hybrid & 7 & 3 & 10 \\
\hline
\end{tabular}

Table 2. Functions of picture in the topics

\begin{tabular}{lccr}
\hline \multirow{2}{*}{$\begin{array}{c}\text { Types of } \\
\text { Pictures }\end{array}$} & \multicolumn{3}{c}{ Curriculum } \\
\cline { 2 - 4 } & KTSP & Kurikulum & Total \\
\hline Narrative & 21 & 12 & 33 \\
Analytical & 54 & 63 & 117 \\
Classificational & 1 & 4 & 5 \\
Metaphorical & 1 & - & 1 \\
\hline
\end{tabular}

The dominant use of realistics pictures is especially appropriate with the topic of Classification of Living Things and Plants Structure. As they maintain similar form with those in the real world, readers' understanding of the materials should then be better facilitated. The use of conventional pictures may not meet a similar goal. Conventional pictures are low in

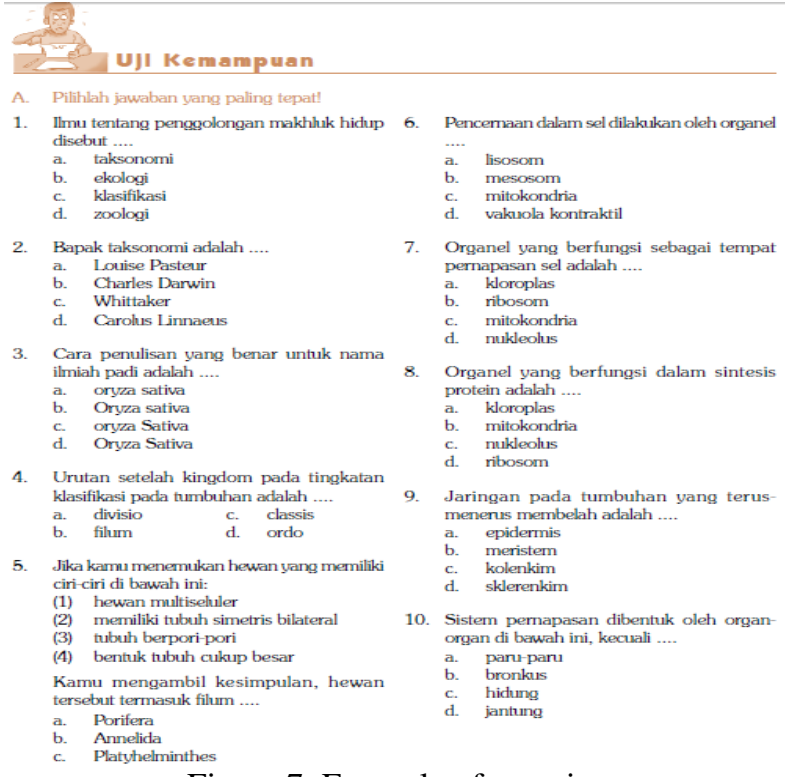

Figure 7. Example of exercise

number in the topics of the textbooks with both curriculums.

In terms of the functions of pictures, analytical pictures, pictures showing part-whole relation are used more dominantly than pictures showing other structures. This is because the topic of Classification of Living Things and Plant Structures significantly discuss plants taxonomy. Metaphorical pictures are very limited in number in all the topics investigated. It is in the form of the picture of a scientist with a certain pose. The limited number of metaphorical pictures is also appropriate as scientific texts are intended to present information with denotative rather than connotative meanings as metaphorical or symbolical pictures have.

Figure 8 below is an example of the analytical picture found. The picture shows a flower with its parts labelled. The linguistic equivalent of the picture is "this flower consists of.." Figure 9 is an example of a picture with a narrative structure. It functions to depict a process or an action that is going on.

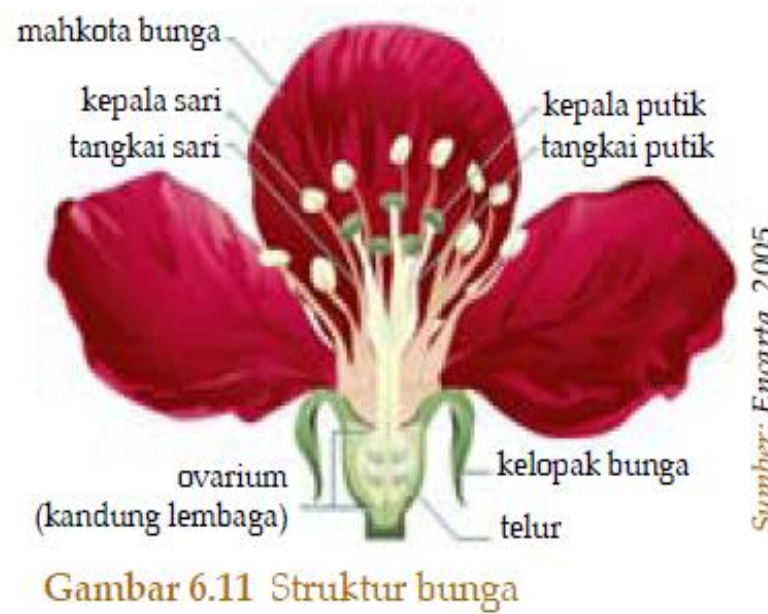

Figure 8. Example of analytical picture 


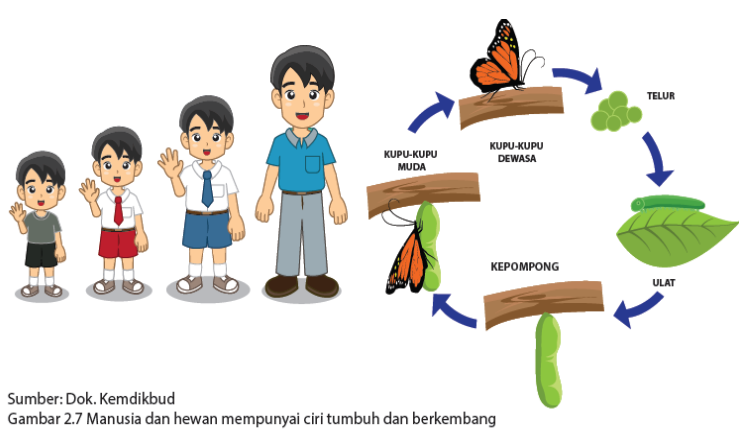

Figure 9. Example of narrative structure picture

The imaginary vector that we can draw from the picture of the smallest kid to the picture of a fully grown up man represents the movement of the growth humans experience. The arrow in the second picture represents the process taking place for a worm to turn into a beautiful butterfly.

Figure 10 and 11 are a self-portrait of two important scientists in their respective field. The pictures do not represent any unfolding action nor a part-whole structure.

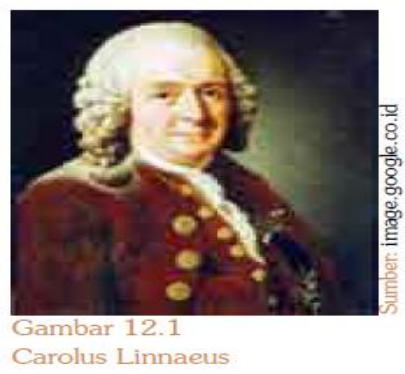

Figure 10. Picture of Carolus Linnaeus

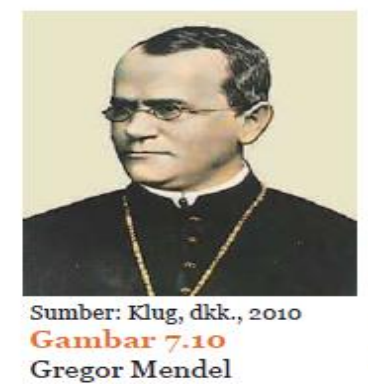

Figure 11. Picture of Gregor Mendel

They, instead, show meaning beyond their literal meaning. In short, they are metaphorical or something. The attire, the wig and the suit, worn by Carolous Linnaeus were the common attire used by the people in the eighteenth century (Jones, 2010). They were usually worn by noble and people of high social status. The attire worn by Gregor Mendel represents the common attire worn by priests. The attire and the pose of the represented participants clearly represent the position of science in their time. In the case of Gregor Mendel, science and scientific endeavor are represented as the endeavor done by simple men that can be motivated by religious belief. Those pictures are examples of metaphorical or symbolical pictures.

\section{Pictures formality and modality}

In terms of the formality or modality of images used, it was found that the pictures which use full-color modulation are dominantly used. These pictures are considered high in modality and low in formality $(\mathrm{KvL}$ 2006; Dimopoulos, et al., 2003). Figure 12 below is an example of high modality and low formality picture, while Figure 13 is an example of a low modality and high formality picture.

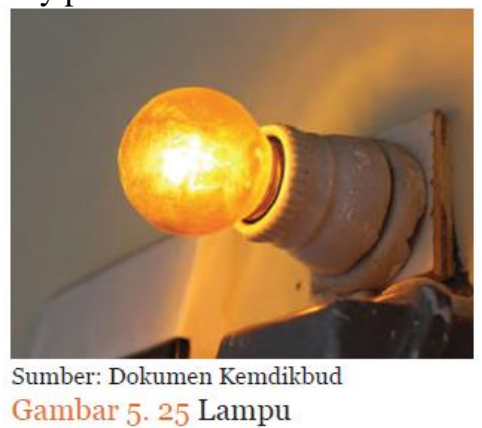

Figure 12. Example of high modality and low formality picture

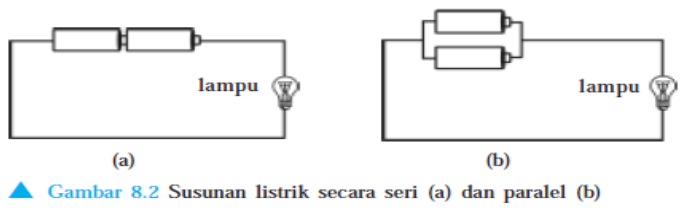

Figure 13. Example of low modality and high formality picture.

Pictures that use full colour often maintain the likeness with the objects in the real world. These pictures are considered appropriate to be used for students in the early grade as they help them relate the objects that they see everyday in their world with those scientifically studied in the classroom. As they move on to a higher level, the pictures they observe in their textbooks gradually become low modality pictures. This is true with the topics investigated. The low modality but high formality pictures are used more frequently in grade 9 than in grade 7 .

\section{Ideational meanings of verbal texts Results of transitivity analysis}

Relational process, attributive identifying, and material process, a process of doing and happening, existential process, and mental process, a process which concerns with our own experience of the world of our own consciousness, are the most frequently used processes in the reading texts. The following is extracts from reading passages of the topics investigated. Due to space constraint, only two extracts, one from Classification of Living Things and one from Dynamic Electricity can be shown here.

Extract 1

1. Klasifikasi Makhluk Hidup

1. Pada 1969 (circurmtance), ilmuwan Biologi R. H Whittaker (actor), membagi (material) makhluk hidup (goal) menjadi (material) lima kingdom, yaitu kingdom monera, protista, fungi, plantae, dan animalia. (scope) 
2. Sistem ini (goal) banyak (circumtance) digunakan (material) para ilmuwan biologi (actor).

3. Pembagian lima kingdom ini (goal) didasarkan (material) pada susunan sel dan cara hidup dalam pemenuhan kebutuhan makanan. (actor)

4. Klasifikasi tersebut (token) adalah (relational) sebagai berikut (value).

a. Monera

5. Ciri-ciri monera (carrier) adalah (relational) uniseluler (bersel tunggal), sel prokariotik (tidak memiliki membran inti), dan memiliki reproduksi secara aseksual. (atribute)

1) Bakteri

6. Bakteri (carrier) memiliki (relational) sel uniseluler dan prokariotik.(atribute)

7. Umumnya tidak memiliki klorofil, (atribute)

8. namun ada yang (carrier) memiliki (relational) klorofil (atribute)

9. sehingga dapat melakukan (material) fotosintesis (scope).

10. Ukuran bakteri (carrier) sangat kecil (atribute), hanya beberapa mikron (atribute).

11. a) Berdasarkan bentuknya (circumtance), bakteri (goal) dibagi (material) menjadi tiga macam, (scope)

12. yaitu: (1) Kokus (bulat) Contoh (token) : (relational) Staphylococcus aureus (penyebab radang paruparu) (value)

13. (2) Basil (batang) Contoh (token): (relational) Bacillus anthracis (penyebab antraks) (value)

14. (3) Spiral (berbengkok-bengkok) Contoh (token) : (relational)Treponema pallidum (penyebab sifilis) (value)

Extract 2

Mengukur Kuat Arus Listrik

1. Dalam kehidupan sehari-hari, (circumtance) kamu (senser) dapat (modal) mengamati (mental) adanya gejala beda potensial (phenomenon) di baterai atau akumulator (circumtance).

2. Beberapa baterai (goal) dapat (modal) disusun (material) secara seri maupun paralel. (circumtance)

3. Yang dimaksud susun seri (value) adalah (relational) kutub positif disambungkan dengan kutub negatif lainnya. (token)

4. Adapun, untuk susun paralel (value) adalah (relational) kutub-kutub yang sejenis disatukan (token).

5. Untuk lebih jelasnya (circumtance) perhatikan (mental) Gambar 8.2. (phenomenon)

6. Untuk susun seri (actor) akan (modal) menghasilkan (material) kuat arus listrik yang lebih besar daripada rangkaian susunan paralel. (goal)

7. Hal itu (goal) disebabkan (material) oleh bertambahnya beda potensial. (actor)

8. Karena itu (circumtance) jika kedua macam rangkaian itu (goal) digunakan untuk menyalakan (material) lampu (goal), akan (modal) menghasilkan (material) nyala yang berbeda. (goal)

9. Dapatkah kamu (senser) menjelaskan (verbal) hal tersebut? (verbiage)

The first part of the extract 1 (clauses 1-4) from Klasifikasi Makhluk Hidup, talks about what a biologist did; laying the foundation for the classification of the living things. This is achieved through the use of material processes which tell what he did. The second part of the extract above shows two entities, Monera and Bacteria, which are described. The description centers on the features they have. This is achieved through the use of a relational process which relates the entity to their features or other entities.

In the extract 2, along with material and relational processes, the text uses mental process. The use of mental process often position the readers as the observer of a natural phenomenon or the object discussed in the text.

Based on the use of processes in the text, we can sum up that the scientific messages communicated in the reading passages mostly center on the existence of a phenomenon/object or entities, what the entity/ies and the objects are like, what they do, or are done to them, how readers should observe the phenomena/objects, and what scientists do.

\section{Interpersonal meanings of the verbal text}

In relation to the genre used, it is found that the main passage used multimodal text genre (Bateman 2008). The topics use a text that combines verbal text, mathematical symbol despite being simple, and pictures. In term of how the idea is organised, the texts mostly identify a natural object/entity/phenomenon then describe it; hence, report texts. Further, these texts are categorised, according to the types of texts used in science (Martin and Rose, 2007), into a multimodal taxonomical report and multimodal descriptive report.

A multimodal taxonomical report is used in the topic of Classification of Living Things as can be seen on the extract. The text presented a different living organism categorised into a taxon and described their features. The multimodal descriptive report is used in the other two topics. The text centers around an object; it identifies the object then proceeds with describing its features. Text in extract 2 can be categorised into a multimodal descriptive report. The original text contains two pictures as can be seen in Figure 14.

Dalam kehidupan sehari-hari, kamu dapat mengamati adanya gejala beda potensial di baterai atau akumulator. Beberapa baterai dapat disusun secara seri maupun paralel. Yang dimaksud susun seri adalah kutub positif disambungkan dengan kutub negatif lainnya. Adapun, untuk susun paralel adalah kutub-kutub yang sejenis disatukan. Untuk lebih jelasnya perhatikan Gambar 8.2.

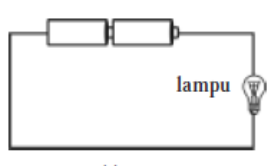

(a)

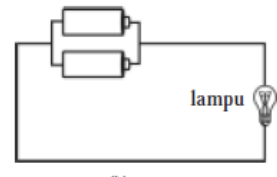

(b)
- Gambar 8.2 Susunan listrik secara seri (a) dan paralel (b)

Untuk susun seri akan menghasilkan kuat arus listrik yang lebih besar daripada rangkaian susunan paralel. Hal itu disebabkan oleh bertambahnya beda potensial. Karena itu jika kedua macam rangkaian itu digunakan untuk menyalakan lampu, akan menghasilkan nyala yang berbeda. Dapatkah kamu menjelaskan hal tersebut?

Figure 14. A multimodal descriptive report 
Pronoun "kamu" (you) is often used in the topics, in the introductory text leading to the main text, to address the readers, in such questions as

(1) "Pernahkah kamu memperhatikan hewan dan tumbuhan di sekitarmu? Coba kamu perhatikan pohon mangga dan pohon durian."

have you ever observed animals and plants in your surrounding? (you) try to observe the manggo and durian tree.

(2) Coba perhatikan meja belajar dan tumbuhan. Apa bedanya meja belajar dan tumbuhan yang ada di sekitarmu? Apakah tumbuhan mempunyai kemampuan untuk tumbuh dan berkembang, bernapas, dan berkembang biak?

(You) try to observe desks and plants. How does the desk differ from the plants around you? Do plants have the ability to grow and develop, to breathe, and to breed?

The pronoun "kamu" is a pronoun used between people of a close relation. "Kamu" is also used to young adults (Sneddon,1996), such those at the age of junior high school students as the textbooks readers. The use of the pronoun in those questions serves both to involve the readers into the discussion on the topic and to negotiate the power relation established between the writer/scientific information and the readers. Readers are positioned as the receivers of the message from someone(s) who are more knowledgable, hence, more powerful than they are but at the same time approachable.

Despite being not many, the reading texts use such modals as "dapat" (can) which is both dynamics and epistemic modalities showing ability and possibility, and "akan" (will) showing predictability, (see example in extract 2). The use of these verbal modalities allows the units of information of the given text to be open for a different opinion and, further, for rejection. On the other hand, the absence of modalities in other information units constructs them as a fact or result of scientific observation that students as readers find hard, if not impossible, to argue against. Hence, they have to just accept them.

The limited and specified use of modalities is expected in science texts, including reading texts in science textbooks as the texts are intended to present grounded, trustworthy information that should not be open to many different interpretations.

\section{Interpersonal meanings in the visual text}

Visually the pictures co-deployed with the verbal text contain one represented participant, use full colour and big size, often with horizontal eye level perspective as the most dominant perspective used as illustrated in Figure 15.

The full-color used allows the picture to resemble the object in the real world. The big size used makes the represented participant in the picture more clearly seen by the readers. Eye-level perspective constructs an equal relation between the readers as the interactive participants with the represented participants and the messages sent by the pictures.

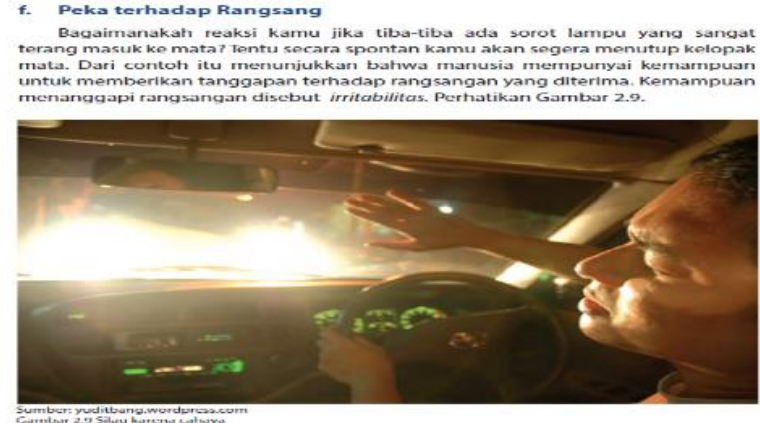

Figure 15. Example of full color, big size, and eye level perspective picture

Most of the pictures used in the topics investigated contain represented participants who do not present any gaze, or when the gaze is present, it is directed not towards the interactive participants but somewhere else. Interpersonally readers are positioned as observers. They are presented with a phenomenon or object to observe, to learn, to make meaning from. This is consistent with the use of the mental process in the verbal text.

\section{CONCLUSIONS}

The paper has, despite being simple and limited, investigated how the different modes, verbal and visual, represent scientific information, hence, the science in science textbooks used for grade 7,8, and 9 in the Indonesian context. The paper also reports how these two different modes construct the (imaginary) interpersonal relation between the readers and the textbook writers/scientific information contained and conveyed in the main texts of the textbooks investigated.

Ideationally, the dominant use of realistic images with low formality and with high modality shows that the textbooks present the world and reality through objects resembling their true form in the real world. The textbooks maintain the likeness of form and colors of the scientific objects students study in schools with their real objects.

This use of realistic images allows the scientific objects studied to look real for students studying them. Such pictures tend to attract students' attention more. Hence, they facilitate the students more when they are asked to describe the objects. The ability to describe scientific objects students study is one of the curriculum-mandated competences.

Based on their functions, analytical pictures showing part-whole relation between represented participants are used more dominantly than pictures of other functions. This shows that the scientific knowledge in the text of the topics/chapters investigated is focused on structure and physical appearance of the entities serving as the scientific objects studied by the students. They are oriented towards understanding important parts constituting the entities and how these parts relate to each other in constituting the entities as a whole. This is consistent with the genre of the text; 
multimodal taxonomical, descriptive reports, which use the relational and material process as the dominant types of processes. Through the use of relational processes, the entities are described (the beings part) and how their parts relate to each other are explained (the relatings part). Material processes used serve to 'add' the entities' important features in term of what they do (the doing part) and what happens with and to them (the happening part).

Interpersonally, the images which are co-deployed with verbal texts are presented using big size allowing the readers to see the represented participants (RP) in the pictures clearly and closely. The perspective dominantly used in the images is horizontal, presenting the images at eye-level with the readers. Dominantly the represented participants (RP) in the picture are without gaze directing towards the interactive participants (IP)/readers. Readers are positioned as having equal power with the scientific messages presented in the textbooks. In other words, the learning materials in the textbooks are the topics students can actually master, not something having more power over the readers; hence, very difficult to learn.

The images used and how they are presented in the topics seem to defy the respondents' belief that the topics are the ones students find most difficult to master. Most probably then, the difficulty is created by other factors that would serve as the next interesting topic to investigate.

\section{REFERENCES}

Alwi, H. (1992). Modalitas dalam Bahasa Indonesia. Jakarta: Kanisius.

Arlitasari, O., Pujayanto., \& Budhiharti, R. (2012). Pengembangan bahan ajar IPA terpadu berbasis saling temas dengan tema biomassa sumber energi alternatif terbarukan. Jurnal Pendidikan Fisika, 1(1),81-88.

Baldry, A. P., \& Thibault, P. J. (2006). Multimodal transcription and text. London: Equinox.

Bateman, J. A. (2008). Multimodality and genre: A foundation for the systematic analysis of multimodal documents. . Basingstoke, UK \& new York: Palgrave MacMillan.

Bernstein, B. (1996). Pedagogy, symbolic control and identity: Theory, research, critique. London: Taylor and Francis.

Best, R. M., Rowe, M., Ozuru, Y., \& McNamara, D. (2005). Deep-level comprehension of science texts. The role of the reader and the text. Topics in Language Disorders, 25(1), 65-83.

Carnel, R.N. \& Levin, J.R. (2002). Pictorial Illustration still improve students' learning from text. Educational Psychology Review, 14(1), 5-26

Darian, S. (2001) More than meets the eye. The role of visuals in science textbooks. LSP \&Professional Communication, 1(1), 10-36.

Dimopoulos, K., Koulaidis, V., \& Sklaveniti, S. (2003). Towards an analysis of visual images in school science textbooks and press articles about science and technology. Research in Science Education, $33,189-216$.

Guo, L. (2004). Multimodality in a biology textbook. In K. L. O'Halloran (Ed..), Multimodal discourse analysis: Systemic-functional perspectives (pp. 196-219). London: Continuum.

Halliday, M. A. K. (1996). On the language of physical science. In M. A. K. Halliday \& J. R. Martin (Eds.), Writing science: Literacy and discursive power (pp. 54-68). London: The Falmer Press.

Halliday, M. A.K., \& Matthiessen, C.M.I.M (2004). Introduction to functional grammar (Third ed.). New York: Hodder Arnold.

Halliday, M.A.K. (1985). An introduction to functional grammar. London: Arnold.

Halliday, M.A.K. (1994). Introduction to functional grammar (2nd ed.). London: Arnold.

Hamdu, G., \& Agustina, L. (2011). Pengaruh motivasi belajar siswa terhdap prestasi belajar IPA di Sekolah Dasar. Studi kasus terhadap siswa kelas IV SDN Tarumanagara Kecamatan Tawang Kota Tasikmalaya. Jurnal Penelitian Pendidikan 12(1), 91-96

Harp, S. F., \& Mayer, R. E. (1997). The role of interest in learning from scientific text and illustrations: On the distinction between emotional interest and cognitive interest. Journal of Educational Psychology, 89(1), 92-102.

Jones, J. (2010). The fleeting art: Fashion and culture in eighteenth century France. Retrieved from: https://pdfs.semanticscholar.org/ab59/6a8aa14994 7ece8dfd45a6d53eab4ccc5fd3.pdf

Kirsh, D. (2002). Why illustration aids understanding. The International workshop on dynamic visualization and learning, (pp. 1-9). Tubingen, Germany.

Kress, G. \& van Leeuwen, T. (1998). (The critical) analysis of newspaper layout. In A. B. Garret (Ed.), Approaches to media discourse (pp. 186219). London: Routledge.

Kress, G., \& van Leeuwen, T (1996). Reading images. The grammar of visual design. London: Routledge.

Kress, G., \& van Leeuwen, T (2006). Reading images. The grammar of visual design (2nd ed.). London: Routledge.

Kress, G., \& van Leeuwen, T. (1992). Structures of visual representation. Journal of Literary Semantics, 21(2), 91-117.

Levin, J. R., \& Mayer, R. E. (1992). Understanding illustrations in texts. In B. K. Britton, A. Woodward, \& M. Binkley (Ed.), Learning from textbook: Theory and practise (pp. 95-114). New Jersey: Lawrence Erlbaum Associates, Inc.

Martin, J. R., \& Rose, D. (2007). Genre relations: Mapping culture. London: Equinox.

Martinec, R. (1998). Cohesion in action. Semiotica, 120(1/2), 161-180.

Martinec, R., \& Salway, A. (2005). A system for imagetext relations in new (and old) media. Visual Communication. 4(3), 339-374 
Mayer, R. E. (1989). Systematic thinking fostered by illustrations in scientific text. Journal of Educational Psychology, 81(2), 240-246.

Mayer, R. E., \& Gallini, J. (1990). When is an illustration worth ten thousand words? Journal of Educational Psychology, 82(4), 715-726.

Mayer, R. E., \& Simms, V. K. (1994). For whom is a picture worth a thousand words? Extensions of a dual-coding theory of multimedia learning. Journal of Educational Psychology, 86(3), 389401.

Mayer, R. E., Hegarty, M., Mayer, S., \& Campbell, J. (2005). When static media promote active learning: Annotated illustrations versus narrated animation in multimodal instruction. Journal of Experimental Psychology: Applied, 11(4) 256265. DOI: 10.1037/1076-898X.11.4.256

O'Halloran, K. (2005). Mathematical discourse: Language, symbolism and visual images. London: Continuum.

O'Toole, M. (1994). Language of displayed art. London: Leicester University Press.

Prasetya, T. (2012). Meningkatkan keterampilan menyusun instrumen hasil belajar berbasis modul interaktif bagi guru guru SMPN kota Magelang. Journal of Educational Research and Evaluation,1(2), 106-112.

Rohima, I., \& Puspita, D. (2009). Alam sekitar IPA terpadu untuk SMP/MTs Kelas VII. Jakarta: Pusat Perbukuan Departmen Pendidikan Nasional.

Rohima, I., \& Puspita, D. (2009). Alam sekitar IPA terpadu untuk SMP/MTs Kelas VIII. Jakarta: Pusat Perbukuan Departmen Pendidikan Nasional.

Royce, T. (2002). Multimodality in the TESOL classroom: exploring visual-verbal synergy. TESOL Quarterly, 36(2), 191-205.
Schnotz, W., \& Kurschner, C. (2007). External and internal representations in the acquisition and use of knowledge: Visualization effects on mental model construction. Instructional Science, 36, 175-190.

Sneddon, J. N. (1996). Indonesian reference grammar. Brisbane: Allen \& Unwin.

Van Leeuwen, T. (2005). Introducing social semiotics. London: Routledge.

Wariyono, S., \& Muharomah, Y. (2008). Mari belajar ilmu alam sekitar. Panduan belajar IPA terpadu untuk kelas IX SMP/MTs. Jakarta: Pusat Perbukuan Departemen Pendidikan Nasional.

Widiatmoko, A., \& Pamelasari, S. D. (2012). Pembelajaran berbasis proyek untuk mengembangkan alat peraga IPA dengan memanfaatkan bahan bekas pakai. Jurnal pendidikan IPA Indonesia, 1(1),51-56.

Widodo, T dkk. (2009). IPA terpadu untuk SMP/MTs kelas VIII. Jakarta: Pusat Perbukuan Departemen Pendidikan Nasional.

Widodo, W., Rachmawati, F., \& Hidayati., S. N. (2016). Ilmu Pengetahuan Alam. SMP/MTs kelas VII. Edisi Revisi. Jakarta: Kementerian Pendidikan dan Kebudayaan.

Wiyono, K., Setiwan, A., \& Suhandi, A. (2009). Model pembelajaran multimedia interaktif relativitas khusus untuk meningkatkan keterampilan generik sains siswa SMA. Jurnal penelitian dan pendidikan IPA, 1(1),21-30.

Zubaidah, S dkk. (2015). Ilmu Pengetahuan Alam SMP/MTs kelas IX. Cetakan kesatu. Jakarta: Kementerian Pendidikan dan Kebudayaan.

Zubaidah, S dkk. (2017). Ilmu Pengetahuan Alam SMP/MTs kelas VIII. Edisi Revisi2017. Jakarta: Kementerian Pendidikan dan Kebudayaan. 